\title{
Erratum to: Lipofilling effects after breast cancer surgery in post-radiation patients: an analysis of results and algorithm proposal
}

\author{
Manuel Debald $^{1}$ - Thomas Pech ${ }^{2,3}$ - Christina Kaiser ${ }^{1}$ Mignon-Denise Keyver-Paik ${ }^{1}$. \\ Gisela Walgenbach-Bruenagel $^{3}$ • Joerg C. Kalff ${ }^{3}$ • Walther Kuhn ${ }^{1}$. \\ Klaus J. Walgenbach ${ }^{2}$ (D)
}

Published online: 5 August 2017

(C) The Author(s) 2017. This article is published with open access at Springerlink.com

\section{Erratum to: European Journal of Plastic Surgery \\ DOI 10.1007/s00238-017-1311-1}

The article Lipofilling effects after breast cancer surgery in postradiation patients: an analysis of results and algorithm proposal, written by Manuel Debald, Thomas Pech, Christina Kaiser, Mignon-Denise Keyver-Paik, Gisela Walgenbach-Bruenagel, Joerg C. Kalff, Walther Kuhn, Klaus J. Walgenbach, was originally published electronically on the publisher's internet portal (currently SpringerLink) on 29 May 2017 without open access.

With the author(s)' decision to opt for Open Choice the copyright of the article changed on 5 August 2017 to (C) The Author(s) 2017 and the article is forthwith distributed under the terms of the Creative Commons Attribution 4.0 International License (http://creativecommons.org/licenses/by/4.0/), which permits use, duplication, adaptation, distribution and reproduction in any medium or format, as long as you give appropriate credit to the original author(s) and the source, provide a link to the Creative Commons license and indicate if changes were made.

The original article has been corrected.

Open Access This article is distributed under the terms of the Creative Commons Attribution 4.0 International License (http:// creativecommons.org/licenses/by/4.0/), which permits use, duplication, adaptation, distribution and reproduction in any medium or format, as long as you give appropriate credit to the original author(s) and the source, provide a link to the Creative Commons license and indicate if changes were made.

The online version of the original article can be found at http://dx.doi.org/ 10.1007/s00238-017-1311-1

Klaus J. Walgenbach

klaus.walgenbach@ukb.uni-bonn.de

1 Department of Obstetrics and Gynecology, Centre for Integrated Oncology, University of Bonn, Bonn, Germany

2 Division of Plastic and Aesthetic Surgery, University of Bonn, Sigmund-Freud-Str. 25, 53127 Bonn, Germany

3 Department of Surgery, Centre for Integrated Oncology, University of Bonn, Bonn, Germany 